\title{
Habitat fragmentation in a seagrass landscape: Patch size and complexity control blue crab survival
}

\author{
KA Hovel \\ Virginia Institute of Marine Science \\ Rom Lipcius \\ VIMS
}

Follow this and additional works at: https://scholarworks.wm.edu/vimsarticles

Part of the Marine Biology Commons

\section{Recommended Citation \\ Hovel, KA and Lipcius, Rom, "Habitat fragmentation in a seagrass landscape: Patch size and complexity control blue crab survival" (2001). VIMS Articles. 1740. \\ https://scholarworks.wm.edu/vimsarticles/1740}

This Article is brought to you for free and open access by the Virginia Institute of Marine Science at W\&M ScholarWorks. It has been accepted for inclusion in VIMS Articles by an authorized administrator of W\&M ScholarWorks. For more information, please contact scholarworks@wm.edu. 


\title{
HABITAT FRAGMENTATION IN A SEAGRASS LANDSCAPE: PATCH SIZE AND COMPLEXITY CONTROL BLUE CRAB SURVIVAL
}

\author{
Kevin A. Hovel ${ }^{1}$ And Romuald N. Lipcius \\ School of Marine Science, College of William and Mary, P.O. Box 1346, Gloucester Point, Virginia 23062-1346 USA
}

\begin{abstract}
Habitat fragmentation is increasingly common on land and in the sea, leading to small, isolated habitat patches in which ecological processes may differ substantially from those in larger, continuous habitats. Seagrass is a productive but fragmented subtidal habitat that serves as a refuge from predation for many animals because its structural complexity limits the detection and capture of resident prey. The singular influence of seagrass habitat fragmentation (e.g., patch size) on faunal survival is largely unknown and has been difficult to quantify because seagrass habitat complexity (e.g., shoot density) and patch size are often confounded and vary seasonally. In early summer 1998 we quantified the effect of seagrass habitat fragmentation on juvenile blue crab (Callinectes sapidus) survival in the absence of covarying complexity by exposing tethered crabs to predators in density-controlled, artificial eelgrass (Zostera marina) plots embedded within natural seagrass patches of four broad size classes $\left(<1 \mathrm{~m}^{2}\right.$ to $\left.>30000 \mathrm{~m}^{2}\right)$. We repeated this experiment in late summer 1998 with three different shoot densities, after predictable environmental events (defoliation and bioturbation) had increased seagrass habitat fragmentation and decreased shoot density. In early summer, crab survival was inversely correlated with seagrass patch area; survival of juvenile blue crabs increased as patch size decreased, in contrast to patterns typically observed in terrestrial and marine systems. This pattern appears to have been due to low abundance of adult blue crabs, the chief predator of juvenile conspecifics, in small patches. In late summer, blue crab survival was greater than in early summer, and survival increased with artificial seagrass shoot density but did not vary with patch size. The breakdown of the relationship between crab survival and patch size in late summer may have resulted from influx of cownose rays, which fragmented large, continuous patches of seagrass into smaller patches in midsummer, potentially equalizing fragmentation across the seagrass meadow. These results show that (1) fragmented seagrass landscapes hold significant refuge value for juvenile blue crabs, (2) fragmentation and crab survival vary temporally, and (3) crab survival increases with habitat complexity (shoot density) regardless of patch size. The findings indicate that habitat patch size and complexity jointly drive organismal survival, and that their influence differs temporally in this dynamic landscape. Thus, ecological processes are sensitive to landscape structure, and studies of habitat structure should incorporate multiple scales of space and time, as well as potentially confounding structural variables.
\end{abstract}

Key words: artificial eelgrass; blue crab; Callinectes sapidus; complexity; habitat fragmentation; landscape ecology; scale; seagrass; survival; Zostera marina.

\section{INTRODUCTION}

As humans sequester more of the Earth's natural habitat for their own use, ecologists have become increasingly concerned with the effects of habitat fragmentation on flora and fauna (Forman and Godron 1981, 1986, Saunders et al. 1991). In the eastern United States, fragmentation of forest habitat produces a landscape of small, isolated forest patches often surrounded by agriculture, which increases the abundance of songbird nest predators (e.g., skunks, raccoons, opossums) and brood parasites (e.g., the Brown-headed Cowbird Molothrus ater) that utilize both cropland and forest

Manuscript received 6 May 1999; revised 17 February 2000; accepted 27 July 2000; final version received 22 August 2000.

${ }^{1}$ Present address: Department of Biology, Sonoma State University, Rohnert Park, California 94928 USA.

E-mail: Kevin.Hovel@sonoma.edu habitat (Brittingham and Temple 1983, Wilcove 1985, Keyser et al. 1998). In fragmented habitats, egg survival rates often are lowest at patch edges (Gates and Gysel 1978, Andrén and Angelstam 1988, Paton 1994), and in small patches with high proportional edge (Paton 1994), because abundant predators and parasites move from patch to patch in search of nests (Andrén and Angelstam 1988). High nest predation and brood parasitism in fragmented forests may be the chief cause of songbird population declines (Brittingham and Temple 1983, Wilcove 1985, Small and Hunter 1988, Andrén 1992, Robinson et al. 1995).

Though increased predation often is correlated with increased edge habitat and decreased patch size, prey survival rates ultimately are governed by the behavior and distribution of predators throughout the landscape, which may strongly depend on the landscape context (Andrén 1994, Donovan et al. 1997, Tewksbury et al. 
1998, Villard et al. 1999). For instance, predator abundance declined with forest fragmentation, and edge and patch size effects on egg survival were not apparent in western Montana where forests are fragmented naturally (Tewksbury et al. 1998). Nest predation was greater at patch edges than in the center of patches in highly and moderately fragmented forest landscapes, but not in unfragmented landscapes in the midwestern United States (Donovan et al. 1997).

Habitat fragmentation studies largely have been restricted to terrestrial habitats such as forests, but many marine habitats, including seagrasses (Orth et al. 1984, Orth 1992, Robbins and Bell 1994), kelp forests (Dayton and Tegner 1984, Dayton et al. 1984, Bologna and Steneck 1993), as well as coral and oyster reefs (Eggleston et al. 1998) are often severely fragmented. Seagrass is a highly productive subtidal vegetation that serves as nursery area for many species and supports a high density and diversity of fishes and invertebrates in coastal marine habitats (Peterson 1918, Heck and Orth 1980, Orth 1992). Seagrass is fragmented by waves and currents, burrowing and bottom-feeding animals, and boaters and fishers into patches ranging in size from less than one square meter to thousands of square meters (Orth 1977, 1992, Fonseca et al. 1982, Townsend and Fonseca 1998). Seagrass serves as a refuge for many species because the structural complexity of emergent shoots (measured as shoot density, leaf biomass, or leaf surface area) inhibits the detection and capture of prey by predators (Orth 1992). The refuge value of seagrass therefore generally increases with complexity (Stoner 1979, Heck and Crowder 1990, reviewed by Orth et al. 1984 and Orth 1992).

Processes governing floral and faunal responses to habitat fragmentation on land may act in fragmented seagrass habitats as well (Robbins and Bell 1994), leading to lower prey survival in small, isolated seagrass patches (Irlandi 1994, 1997, Irlandi et al. 1995). However, the effects of seagrass fragmentation and complexity on prey survival are difficult to distinguish because they often covary, with larger seagrass patches having higher shoot densities or biomass (Irlandi 1994, 1997). Moreover, seasonally associated changes in seagrass complexity and fragmentation may alter this relation temporally.

We tested the effects of seagrass habitat fragmentation on the blue crab, Callinectes sapidus Rathbun, in Chesapeake Bay. The blue crab is a ubiquitous decapod crustacean that inhabits shallow estuarine and coastal waters of the Eastern and Gulf coasts of North America (Williams 1984). In Chesapeake Bay, adult females release larvae at the bay mouth from June to September (Van Engel 1958, McConaugha et al. 1988). Larvae develop through seven or eight zoeal stages on the continental shelf and reinvade Chesapeake Bay as postlarvae in summer and fall (van Montfrans et al. 1990). These small, vulnerable postlarvae settle in seagrass and metamorphose to the juvenile form. Seagrass provides young juvenile crabs with both food (e.g., small crustaceans and mollusks) and cover from predators, thereby forming a critical nursery area for blue crabs in Chesapeake Bay. Blue crabs are cannibalistic; larger conspecifics, as well as finfish, are the chief predators of young juveniles (Hines et al. 1990, Mansour 1992, Moody 1994, Moksnes et al. 1997).

We quantified the effect of seagrass fragmentation on juvenile blue crab survival in the absence of covarying complexity by exposing crabs to predators in artificial seagrass plots embedded within naturally occurring seagrass patches. This methodology allowed us to examine survival over the entire range of naturally occurring seagrass patch sizes at our study site, which spanned several orders of magnitude, and further allowed us to quantify the interactive effect of complexity and habitat fragmentation on survival. Our study is the first to test for seagrass habitat fragmentation effects on faunal survival in the absence of covarying seagrass complexity while incorporating a natural range of seagrass habitat fragmentation common to many shallow estuaries such as Chesapeake Bay.

\section{Methods}

\section{Study region and landscape characteristics}

In Chesapeake Bay, the seagrass Zostera marina L. (eelgrass) forms extensive meadows composed of discrete patches ranging from $<1 \mathrm{~m}^{2}$ to $>10000 \mathrm{~m}^{2}$ at shoot densities of 300-3000 shoots $/ \mathrm{m}^{2}$ (Orth and Moore 1986). Our study region was the Z. marina meadow adjacent to the Goodwin Islands $\left(76^{\circ} 24^{\prime} \mathrm{W}\right.$, $37^{\circ} 13^{\prime} \mathrm{N}$ ), a group of small, unpopulated landforms within a Chesapeake Bay National Estuarine Research Reserve in the lower York River (Fig. 1). The islands are separated from the shoreline by a narrow channel $\sim 1 \mathrm{~km}$ wide. We chose this region because it contains a range of seagrass habitat configurations, from large, continuous areas of seagrass to areas with few small seagrass patches surrounded by unvegetated sediment; these "zones" of fragmentation are generated primarily by waves, currents, and bottom-feeding animals. Depths at low tide within these seagrass beds are $\sim 0.5$ $\mathrm{m}$. Mean daily water temperature and salinity in the lower York river vary annually from $4^{\circ}$ to $28^{\circ} \mathrm{C}$ and 16 to 22 psu, respectively.

Eelgrass fragmentation and complexity vary seasonally in Chesapeake Bay. Shoot density and biomass peak in early summer (June-July) when growth is robust, but are lower and more variable among patches in late summer (August-September) after a rapid temperature-induced defoliation (Orth and Moore 1986; K. A. Hovel; and R. N. Lipcius, personal observation). Cownose rays (Rhinoptera bonasus) invade seagrass beds in midsummer in the Chesapeake Bay and increase seagrass fragmentation by excavating seagrass to feed on infaunal bivalves such as hard clams (Mercenaria mercenaria) and soft-shell clams (Mya arenaria) (Orth 


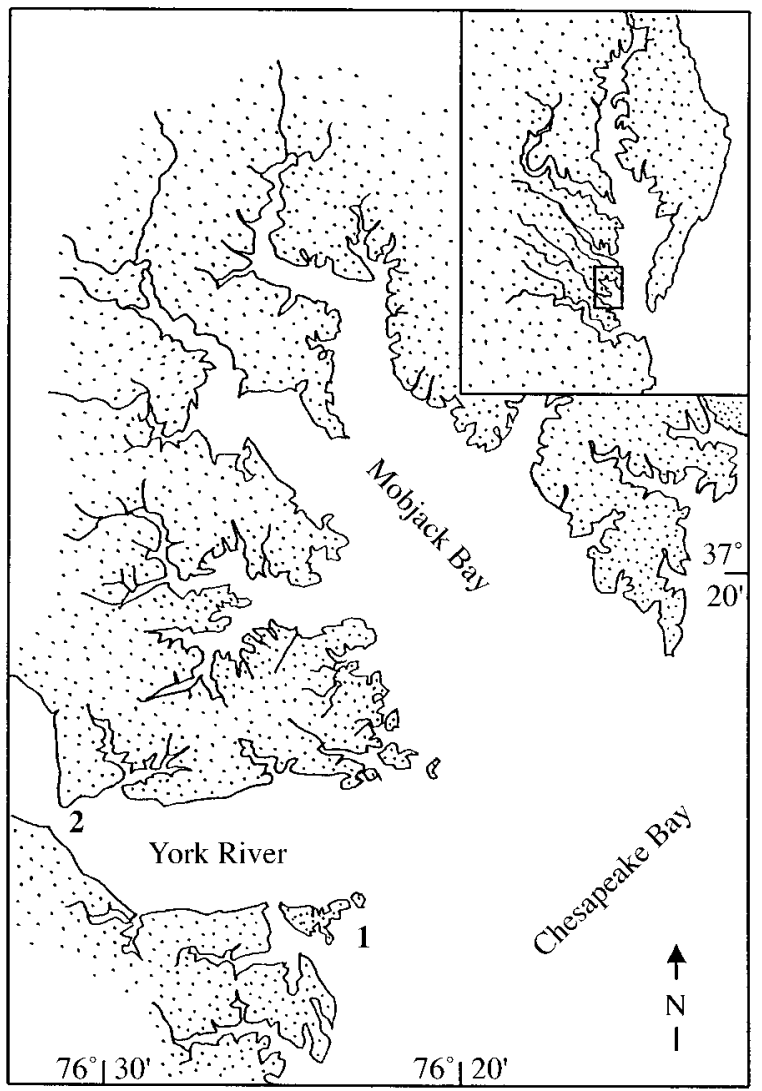

FIG. 1. Map of Chesapeake Bay, Virginia, showing the study site in the lower York River. Tethering experiments and predator trawls were conducted at the Goodwin Islands (1), and laboratory experiments were conducted at the Virginia Institute of Marine Science in Gloucester Point (2), five miles NW of the Goodwin Islands.

1975, Townsend and Fonseca 1998; K. A. Hovel and R. N. Lipcius, personal observation). Thus, seagrass complexity rapidly decreases and seagrass fragmentation rapidly increases within our study area in midsummer.

\section{Selection of study sites}

We used aerial photography and geographic information systems (GIS) to view the entire extent of our seagrass landscape, and then identified areas of seafloor ("fragmentation types") with different combinations of seagrass patch size and isolation. Eight color $20 \times$ $20 \mathrm{~cm}$ overhead photographs (two overlapping transects of four photos each) were taken from a small plane flying at an altitude of $400 \mathrm{~m}$ in May 1998. Each photo covered an area of $240000 \mathrm{~m}^{2}$, and the two transects encompassed the entire seagrass landscape. Before photographs were taken, we affixed one $1 \times 1 \mathrm{~m}$ white Styrofoam board to each of 25 permanent $3 \mathrm{~m}$ high stakes dispersed evenly throughout the meadow, and obtained the position of each board (accuracy $\pm 1 \mathrm{~m}$ ) with a Trimble Geoexplorer handheld differential GPS
(Trimble Navigation Limited, The Woodlands, Texas). These boards were visible in the photographs and served as georeferenced points for rectification. Photographs were scanned at 300 dots per inch, rectified, and combined into a digital mosaic showing the entire seagrass meadow in ARC/INFO (Environmental Systems Research Institute, Redlands, California). This mosaic consisted of $21 \times 21 \mathrm{~cm}$ pixels that were classified as "seagrass" or "unvegetated sediment" using a classification algorithm in ARC/INFO.

To maximize our ability to detect landscape-scale effects on crab survival, we visually delineated four fragmentation types that maximized differences in seagrass patch size and isolation (Fig. 2). We then verified differences in fragmentation types using (1) the zonal geometry function in ARC/INFO to quantify mean patch size in each fragmentation type, and (2) an ARC/ INFO algorithm (D. Wilcox, Virginia Institute of Marine Science, Gloucester Point, Virginia) to quantify mean patch connectivity in each fragmentation type. This algorithm grouped adjacent patches into a "cluster" if their centroids were within a given threshold distance. We then calculated the "radius of gyration" of each cluster as

$$
R_{s}=1 / n \times \sum\left\{\left(x_{i}-\langle x\rangle\right)^{2}+\left(y_{i}-\langle y\rangle\right)^{2}\right\}^{1 / 2}
$$

where $R_{s}=$ the radius of gyration for cluster $s, n=$ the total number of grid cells in the cluster, $\langle x\rangle$ and $\langle y\rangle$ are the mean $x$ and $y$ coordinates of the cluster, and $x_{i}$ and $y_{i}$ are the coordinates of the $i$ th grid cell in the cluster (Keitt et al. 1997). Connectivity was then calculated for each fragmentation type as

$$
C=\sum\left(n_{s} R_{s}\right) / \sum n_{s}
$$

where $C=$ connectivity in meters, $n=$ the number of grid cells in cluster $s$, and $R_{s}=$ the radius of gyration for cluster $s$ (Keitt et al. 1997). We calculated connectivity for threshold distances of $0.25,0.5,0.75,1,2$, 4,5 , and $8 \mathrm{~m}$ in each fragmentation type. Given any random vegetated point on the landscape, $C$ is the average distance an individual will move before encountering unvegetated sediment outside the cluster threshold distance (Keitt et al. 1997).

Two fragmentation types were categorized as "isolated"; the first consisted of single large seagrass patches $\left(\right.$ area $\left.=1000-3000 \mathrm{~m}^{2}\right)$ separated by at least $20 \mathrm{~m}$ of unvegetated sediment, and the other consisted of clusters of four to five very small $\left(\right.$ area $\left.<1 \mathrm{~m}^{2}\right)$ seagrass patches. Each patch in a cluster was $\sim 5 \mathrm{~m}$ from the others, and patch clusters were typically $>50 \mathrm{~m}$ away from any other seagrass. Two fragmentation types were categorized as "connected"; the first was a large zone $\left(\right.$ area $\left.=30000 \mathrm{~m}^{2}\right)$ of nearly continuous seagrass cover, and the other connected fragmentation type was formed by small patches (area $=10-100 \mathrm{~m}^{2}$ ) found along the fringe of this continuous area. These small patches were typically separated $\leq 1 \mathrm{~m}$. Patch area and connectivity measurements are shown in Table 1 . Our frag- 

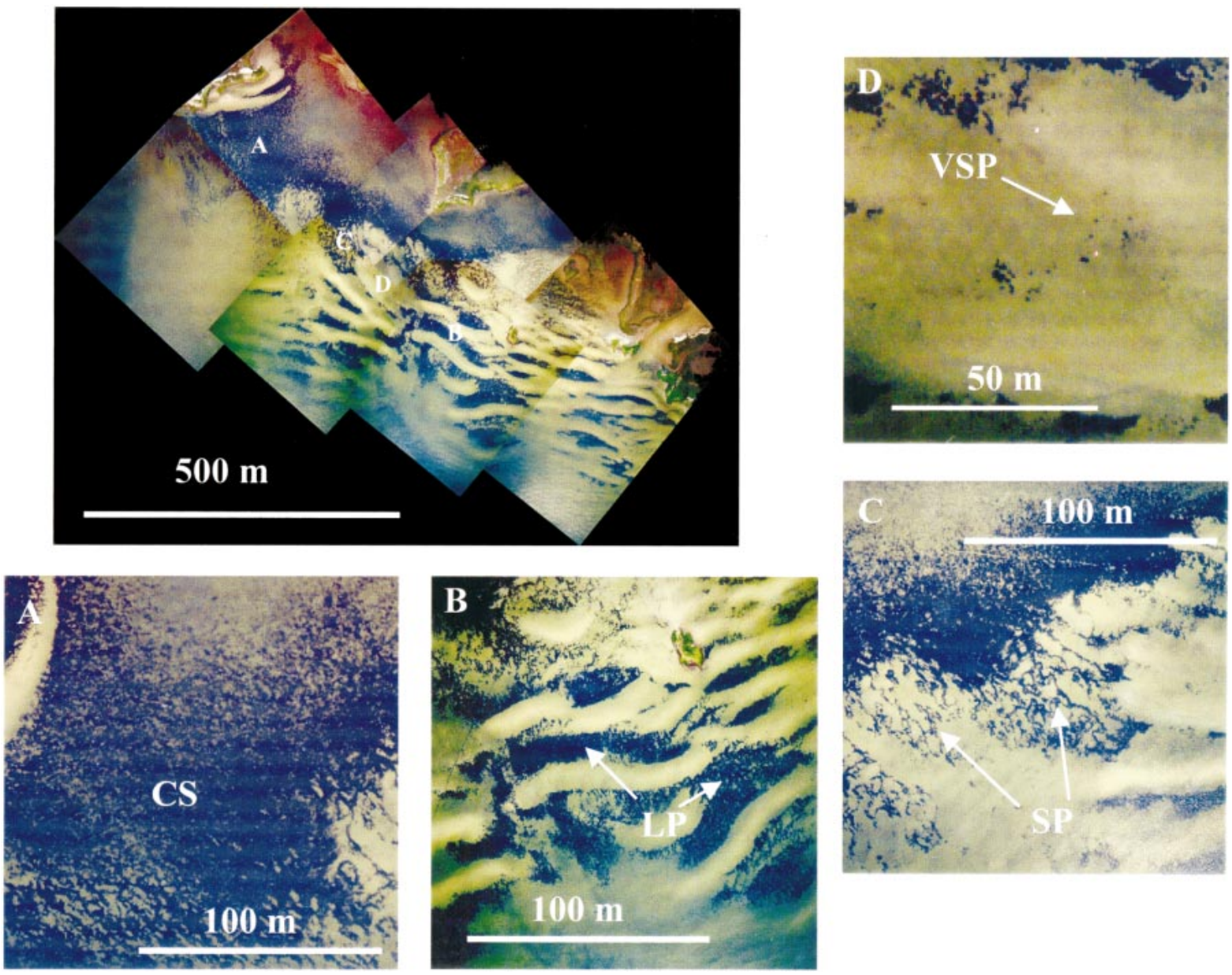

FIG. 2. Aerial photographs of the seagrass landscape adjacent to the Goodwin Islands in the lower York River, Virginia. The digital photographic mosaic used to select fragmentation types is shown in the upper left-hand corner. Panels surrounding the mosaic (A-D) are close-ups from the mosaic showing example patches from each fragmentation type (letters overlaid on the mosaic correspond to panels). Fragmentation types are continuous seagrass (CS), large patches (LP), small patches (SP), and very small patches (VSP).

mentation treatments therefore were: continuous seagrass (connected), large patches (isolated), small patches (connected), and very small patches (isolated).

We randomly selected four points (study sites), each within a seagrass patch, in each of the four fragmentation types and then used GIS to determine the area of the patch surrounding each point. A patch boundary was created when a seagrass pixel was bounded on at least one side by an unvegetated sediment pixel. Thus, seagrass pixels that met at corners were not considered part of the same patch. Because the large patch, small patch, and very small patch fragmentation types were composed of individual patches, a unique patch size measurement was associated with each site in those three fragmentation types. Conversely, all four sites within the continuous seagrass fragmentation type were considered to have the same patch size $\left(\sim 30000 \mathrm{~m}^{2}\right.$; Table 1). We also calculated relative proportional cover at each of these sites at $10 \times 10 \mathrm{~m}\left(100 \mathrm{~m}^{2}\right)$ and 50 $\times 50 \mathrm{~m}\left(2500 \mathrm{~m}^{2}\right)$ extents using a modified crown density scale (Paine 1981, Orth et al. 1996) that categorized seagrass cover as very sparse $(0-10 \%$ cover $)$, sparse $(10-40 \%$ cover $)$, moderate $(40-70 \%$ cover $)$, or dense $(70-100 \%$ cover). Sites were assigned to one of these categories by examining our digital mosaic at each extent and following the methods of Orth et al. (1996). Relative proportional seagrass cover at each of these scales was similar for all patches, and we therefore used proportional cover at the $10 \times 10 \mathrm{~m}$ extent in our analyses. Sites were considered replicates in our analyses; total sample size therefore was $N=16$.

\section{Shoot density measurements}

Though survival experiments were conducted using artificial seagrass plots (see Methods: Blue crab survival) to standardize seagrass complexity among fragmentation types, we compared Zostera marina shoot density among fragmentation types to find if complexity (shoot density) decreased with patch size as in some other seagrass landscapes (e.g., Irlandi 1994, 1997) and 
TABLE 1. Mean patch area and mean connectivity for each fragmentation type in the seagrass landscape.

\begin{tabular}{lcr}
\hline \hline Fragmentation type & Area $\left(\mathrm{m}^{2}\right)$ & $\begin{array}{c}\text { Connectivity } \\
(\mathrm{m}) \dagger\end{array}$ \\
\hline Continuous seagrass $\ddagger$ & 30105 & $263.6^{\mathrm{a}}(14.5)$ \\
Large patch & $3148(607)$ & $105.6^{\mathrm{b}}(30.7)$ \\
Small patch & $8.3(5.5)$ & $246.9^{\mathrm{a}}(20.5)$ \\
Very small patch & $0.3(0.01)$ & $84.5^{\mathrm{b}}(37.9)$ \\
\hline
\end{tabular}

Note: Numbers in parentheses are $1 \mathrm{SE}$.

$\dagger$ Different superscript letters following connectivity measurements denote means that differed in Student-NewmanKeuls (SNK) multiple comparisons. SNK tests followed a one-way, fixed-factor ANOVA $(F=11.5$, df $=3,28, P<$ $0.001)$.

$\ddagger$ The continuous seagrass fragmentation type was not composed of individual patches, precluding calculation of a mean and standard error.

to find if shoot density decreased from late spring to late summer. From 9-11 June 1998, we haphazardly took four $15 \mathrm{~cm}$ diameter $\times 20 \mathrm{~cm}$ deep cores in each of four randomly selected sites within the continuous seagrass, large patch, small patch, and very small patch fragmentation types. We counted the number of $\mathrm{Z}$. $m a$ rina shoots in each core and then averaged shoot counts from the four cores at each site to yield a sample size of $n=16$. Cores were not taken in the same sites in which survival experiments were conducted in order to minimize disturbance to experimental sites. This sampling was repeated on 8-9 August 1998, except that only one core was taken at each randomly selected site $(n=16)$. We used the GLM procedure in SAS (SAS 1990) to run a two-way, fixed-factor analysis of variance (ANOVA) to test if mean shoot density differed among fragmentation types and among the two time periods (June and August). In this and all subsequent tests, we used Cochran's $C$ test to test for homogeneity of variances, and transformed data where necessary to meet the assumptions of ANOVA (Underwood 1997). We based post hoc multiple comparisons on StudentNewman-Keuls tests in this and all subsequent tests.

\section{Blue crab survival experiments}

General methodology.-To test the effects of seagrass fragmentation on crab survival, we tethered juvenile blue crabs (1.0-3.0 cm spine-to-spine carapace width, CW) in artificial seagrass plots of $0.25 \mathrm{~m}$ diameter (Schulman 1996). These plots maintained shoot density constant and precluded confounding effects of food and chemical cues associated with natural seagrass (Schulman 1996, Eggleston et al. 1998). Plots were constructed of Vexar mesh (a woven plastic material) that was sewn to circular steel frames. Segments of buoyant extruded polypropylene ribbon $(0.5 \mathrm{~cm}$ wide $\times 50 \mathrm{~cm}$ long) were folded in two and tied to the Vexar to simulate seagrass shoots. A brass snap swivel was affixed to the center of each plot so that one crab could be tethered in each plot per trial. Crabs were tethered by affixing them to $5-\mathrm{cm}$ segments of mono- filament fishing line with cyanoacrylate glue. This technique is widely used to measure relative survival in crustaceans (e.g., Heck and Thoman 1981, Heck and Wilson 1987, Wilson et al. 1987, Eggleston et al. 1990, Pile et al. 1996, Shulman 1996, Ryer et al. 1997, Lipcius et al. 1998).

Crabs were collected by trawling seagrass beds adjacent to Allen's Island in the lower York River (Fig. 1 ), and were held in running seawater in an outdoor flume. No crab was held $>48 \mathrm{~h}$. Crabs were tethered in the laboratory, measured $(\mathrm{CW})$, and acclimated to tethers for $24 \mathrm{~h}$ in running seawater before placement in the field.

Influence of fragmentation on survival.-The influence of habitat fragmentation in the absence of covarying seagrass shoot density was tested in early summer, before seagrass defoliation and cownose ray invasion. Artificial seagrass plots containing 60 shoots $\left(1200\right.$ shoots $\left./ \mathrm{m}^{2}\right)$ were held in running seawater for 2 wk to condition the ribbon; this shoot density is within the natural range of shoot densities in Chesapeake Bay (Orth and Moore 1986). On 29 June 1998 we placed one plot in each of the four previously selected seagrass patches within each fragmentation type. For this experiment we also created a fifth fragmentation type, which consisted of single artificial seagrass plots placed within each of four randomly located sites in unvegetated sediment. Each of these new sites was at least $20 \mathrm{~m}$ from any naturally occurring seagrass. Thus, "seagrass patches" at these new sites were extremely small $\left(0.05 \mathrm{~m}^{2}\right)$ and well isolated. From 7-20 July 1998, we conducted five 24-h survival trials in each plot (N $=(1 \mathrm{crab} / \mathrm{plot}) \times(4$ plots/fragmentation type/trial $) \times$ $(5$ trials $) \times(5$ fragmentation types $)=100 \mathrm{crabs})$. After $24 \mathrm{~h}$, tethered crabs were checked and categorized as live, eaten (fragments of the carapace remaining on the tether), molted (entire carapace remaining on the tether), or missing (no parts of the carapace remaining on the tether) (Pile et al. 1996). Any crabs remaining alive were released and a new crab then was tethered to each plot. Crabs that molted or died on tethers were excluded from the analysis.

Missing crabs may have escaped from tethers, or may have been pulled off by predators. Adult blue crabs often carry off prey before consuming them (K. A. Hovel, personal observation) and predatory fishes such as puffers also may remove crabs entirely from tethers. To assess the likelihood that missing crabs were pulled off tethers by predators, one plot containing a tethered crab was placed within a galvanized steel cage $(1.0 \mathrm{~cm}$ mesh) in each fragmentation type in each 24-h trial ( $n$ $=5$ crabs per fragmentation type total). After $24 \mathrm{~h}$, all caged crabs remained tethered to plots. Additionally, no crabs escaped from tethers when held for $24 \mathrm{~h}$ before experiments. We therefore assumed that missing crabs had been taken off by predators.

Crab survival was analyzed with a stepwise multiple logistic regression (SAS 1990, Proc LOGISTIC). Crab 
status (live vs. eaten) was the dependent variable; explanatory variables included: (1) connectivity, which was a categorical variable coded as 1 for continuous seagrass and small patches (connected), and 0 for large patches, small patches, and plots placed in unvegetated sediment (isolated); (2) $\log _{10}$ of patch area, measured in square meters, a continuous variable; (3) relative proportional cover, a categorical variable coded as 0 , 1,2 , or 3 for very sparse, sparse, moderate, and dense cover, respectively; (4) crab carapace width measured in millimeters, which was a continuous variable; and (5) trial (day of tethering). We used the log of patch area as an explanatory variable because patch area varied over five orders of magnitude. Only those explanatory variables predicting crab survival at $P<0.05$ entered into the final model. Any model not meeting the goodness-of-fit criteria of Hosmer and Lemeshow (1989) was rejected.

Influence of fragmentation and shoot density on survival.-We conducted a second tethering experiment in September, after shoot density had decreased due to seagrass defoliation (see Results: Shoot density) and cownose rays had invaded our study area and severely fragmented much of the seagrass meadow. We maintained the original borders between our seagrass fragmentation types; thus, this second experiment allowed us to determine if the relative effects of seagrass fragmentation on juvenile blue crab survival differed before and after these major disturbances. Additionally, we varied artificial seagrass shoot density around tethered crabs, enabling us to quantify the interactive effect of shoot density and seagrass fragmentation on crab survival. We tethered crabs in artificial seagrass plots as before, but each plot contained either 15,30 , or 60 artificial seagrass shoots (300, 600, and 1200 shoots/ $\mathrm{m}^{2}$, respectively). On 10 September 1998, one plot of each density was placed at each of four randomly, newly selected sites within the continuous seagrass, large patch, and very small patch fragmentation types $(n=$ 4 plots/density/fragmentation type). A cage was placed over an additional fourth plot of a randomly selected density at each site to control for missing crabs; as above, no caged crabs were missing from tethers after $24 \mathrm{~h}$. All plots were 5-10 $\mathrm{m}$ from one another to prevent nonindependence within sites. From 11-25 September 1998, we conducted 10 24-h survival trials in each plot as described above $(N=[1 \mathrm{crab} / \mathrm{plot}] \times[4 \mathrm{plots} / \mathrm{den}-$ sity/fragmentation type $] \times[3$ fragmentation types $] \times$ [10 trials $]=120$ crabs $)$.

Our digital photographic mosaic of the seagrass landscape was not a good predictor of seagrass patch size, connectivity, or proportional seagrass cover in September due to changes in seagrass habitat configuration by cownose ray foraging. Therefore, we treated fragmentation type as a categorical variable, and used a stepwise multiple logistic regression (SAS 1990, Proc LOGISTIC) to test if crab survival (live vs. eaten) was dependent on fragmentation type, artificial seagrass shoot density, and time (day of tethering).

\section{Temporal changes in survival}

We tested for temporal (July vs. September) differences in crab survival within the continuous seagrass, large patch, and very small patch fragmentation types. Temporal differences in survival could only be tested in high density (1200 shoots $/ \mathrm{m}^{2}$ ) plots within these three fragmentation types, as this was the only density used in both early and late summer. Because day was not a significant explanatory variable in either of the logistic regressions (see Results: Crab tethering), we pooled survival data from all days of each tethering experiment to yield survival frequencies (total number of survivors/total number of tethered crabs per fragmentation type for each tethering experiment). We then used a log-linear model ( $G$ test for goodness of fit; Sokal and Rohlf 1995) to test if survival frequency was dependent on fragmentation type and month (July vs. September).

\section{Predator abundance}

We quantified the abundance of potential predators in each fragmentation type by trawling and suction sampling. On 21-22 August 1998, we conducted four replicate 2-min trawls in each fragmentation type with a $5-\mathrm{m}$ otter trawl $(2.5 \mathrm{~cm}$ mesh $)$ towed behind a small boat. Each replicate tow covered $\sim 400 \mathrm{~m}^{2}$ of seafloor (100 m length $\times 4 \mathrm{~m}$ width) and was conducted so that the trawl did not stray into any adjacent fragmentation types. All crabs and fishes captured in the nets were measured (CW for crabs and total length [TL] for fishes) and released. Though 11 total species were captured in tows (Table 2), we used the number of blue crabs $\geq 50 \mathrm{~mm} \mathrm{CW}$ as an estimate of predator abundance in statistical analyses because adult and subadult blue crabs were the most common items captured in trawls (Table 2), and because they are a major predator on juvenile conspecifics (Darnell 1959, Tagatz 1968, Martin et al. 1989, Peery 1989, Hines et al. 1990, Mansour 1992, Moody 1994). We used a one-way, fixed-factor ANOVA to test if the mean number of large blue crabs per tow differed among the four fragmentation types. We also pooled data from the connected (continuous seagrass and small patches) and isolated (large and very small patches) fragmentation types and used a $t$ test to test for differences in predatory crab abundance between connected and isolated habitat configurations. We used a Bonferroni-adjusted $\alpha$ value of 0.025 in both the ANOVA and $t$ test to correct for inflated significance due to multiple tests.

Trawling measured the overall abundance of potential predators in each fragmentation type. However, if large blue crabs are not commonly found over unvegetated sediment, trawling may have underestimated the number of predators present in patchy seagrass because trawls were conducted along broad areas of bot- 
TABLE 2. Mean number of crustaceans and fishes captured in otter trawls of the seagrass beds in August 1998.

\begin{tabular}{lcccc}
\hline \hline & \multicolumn{2}{c}{ Fragmentation type $\dagger$} \\
\cline { 2 - 5 } Common name and species & CS & SP & VSP \\
\hline Crustaceans & & & \\
Blue crab Callinectes sapidus & $36.7(9.3)$ & $6.3(2.6)$ & $26.5(8.9)$ & $6.8(1.7)$ \\
Fishes & & & \\
Silver perch Bairdiella chrysoura & $19.0(6.1)$ & $0(0)$ & $6.3(4.0)$ & $2.5(1.3)$ \\
Spot Leiostomus xanthurus & $1.8(0.3)$ & $3.8(1.7)$ & $1.3(0.9)$ & $3.5(2.2)$ \\
Northern puffer Diodon hystrix & $0.3(0.3)$ & $0.3(0.3)$ & $0.3(0.3)$ & $0(0)$ \\
Naked goby Gobiosoma bosci & $0.8(0.5)$ & $0.3(0.3)$ & $1.0(1.0)$ & $0.3(0.3)$ \\
Spadefish Chaetodipterus faber & $2.5(0.6)$ & $0(0)$ & $1.8(1.0)$ & $0(0)$ \\
Pipefish Syngathus spp. & $2.0(1.4)$ & $0.3(0.3)$ & $0.0(1.9)$ & $0.8(0.8)$ \\
Pigfish Orthopristis chrysoptera & $0.5(0.5)$ & $0(0)$ & $0(0)$ & $0(0)$ \\
Flounder Paralichthys dentatus & $0.5(0.3)$ & $0(0)$ & $0(0)$ & $0(0)$ \\
Blenny Hypsoblennius hentzi & $0.3(0.3)$ & $0(0)$ & $0(0)$ & $0(0)$ \\
Speckled trout Cynoscion nebulosus & $0.5(0.3)$ & $0(0)$ & \\
\hline
\end{tabular}

Note: Mean number (with $1 \mathrm{SE}$ in parentheses) of individuals captured in $n=4$ replicate tows.

$\dagger$ Fragmentation types: $\mathrm{CS}=$ continuous seagrass, $\mathrm{LP}=$ large patch, $\mathrm{SP}=$ small patch, $\mathrm{VSP}=$ very small patch.

tom. We therefore supplemented our trawling data by suction sampling for large blue crabs in each fragmentation type. Suction sampling allowed us to (1) test whether large blue crabs are found primarily in seagrass or over unvegetated sediment, and (2) further test for differences in predatory crab abundance in seagrass among the four fragmentation types. On 6 August 1998 we haphazardly deployed one $1.46 \mathrm{~m}$ diameter suction ring (see Pile et al. 1996 for description) in each of four large, small, and very small seagrass patches, and one ring in unvegetated sediment nearby each patch $(N$ $=4$ rings/bottom type/fragmentation type). All eight rings were deployed in seagrass in continuous seagrass. Each ring was sampled for crabs by suctioning for 6 min with an underwater suction dredge, followed by 3 min of dipnetting (Pile et al. 1996). We used a oneway, fixed-factor ANOVA to test for differences in the mean number of crabs captured in suction samples (vegetated samples only). To test for differences in crab abundance between seagrass and unvegetated sediment, we used a paired $t$ test on pooled data from the large patch and small patch fragmentation types. The very small patch fragmentation type was excluded from this analysis because crab abundance in suction samples was effectively zero (i.e., only one crab in eight samples).

Finally, we obtained estimates of the general abundance of large blue crabs in the lower York River in both early and late summer to find if differences in juvenile blue crab survival between July and September could be attributed to differences in potential predator abundance. We calculated the mean number of large crabs ( $\geq 50 \mathrm{~mm} \mathrm{CW})$ captured per tow in both July ( $n$ $=4)$ and September $(n=5) 1998$ by the Virginia Institute of Marine Science Juvenile Fish and Blue Crab Trawl Survey. We then tested for differences in mean crab abundance between July and September with a $t$ test.

\section{Treatment-specific bias experiments}

Though tethering is commonly used to measure relative predation rates among treatments, it may produce a biased measure of predation if tethering effects are not proportional across treatments (Peterson and Black 1994, Pile et al. 1996). This may be especially problematic when tethering is used to assess the influence of seagrass shoot density on survival, because crab tethers may get tangled with shoots in high seagrass densities, but not in low densities. Such treatment-specific bias would preclude interpretation of density effects on relative survival. We therefore conducted a full-factorial laboratory experiment to assess the effect of tethering upon bias in treatments involving artificial seagrass density and predator presence or absence.

Four artificial plots each of moderate seagrass density $\left(600\right.$ shoots $\left./ \mathrm{m}^{2}\right)$ and high seagrass density (1200 shoots $/ \mathrm{m}^{2}$ ) were placed in each of two 2000-L mesocosms filled with sand to a height of $0.25 \mathrm{~m}$ and York River water to a depth of $0.5 \mathrm{~m}$. Each plot was encircled with a $1.0 \mathrm{~m}$ diameter $\times 0.75 \mathrm{~m}$ high mesh cage that was pushed into the sand, forming eight arenas in each mesocosm. For each artificial seagrass density, one arena in each mesocosm was chosen at random to receive one of the following treatment combinations: (1) tethered crab (10-30 $\mathrm{mm} \mathrm{CW}$ ) with predator, (2) tethered crab without predator, (3) untethered crab with predator, and (4) untethered crab without predator. Predators were adult blue crabs (80-120 mm CW) captured from trawls at Allen's Island, starved for $48 \mathrm{~h}$ before each 24-h trial, used once, and then released. Six 24-h trials were run in each mesocosm between 24 August and 1 September 1998 ( $n=12$ crabs per treatment combination). After $24 \mathrm{~h}$, we recorded tethered crab status (live, eaten, missing, molted).

We used a $G$ log-likelihood statistic to test if survival was independent of tethering (tethered vs. untethered) and shoot density. Treatment-specific bias is indicated 


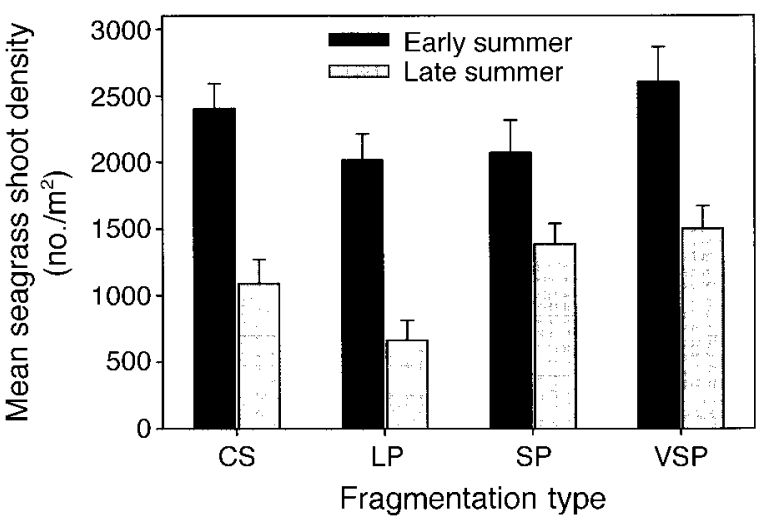

FIG. 3. Mean Zostera marina shoot density ( $+1 \mathrm{SE})$ in the four fragmentation types in early summer and late summer. Fragmentation types are CS (continuous seagrass), LP (large patches), SP (small patches), and VSP (very small patches).

by a significant interaction effect between tethering and shoot density (Peterson and Black 1994, Pile et al. 1996).

\section{RESULTS}

\section{Shoot density measurements}

As expected, there was a twofold reduction in Zostera marina shoot density from June to August (Fig. 3, Table 3). There was no difference in shoot density among the continuous seagrass, large patch, and small patch fragmentation types in either early or late summer, though density was significantly higher in the very small patch than in the large patch fragmentation type in both seasons (Fig. 3, Table 3).

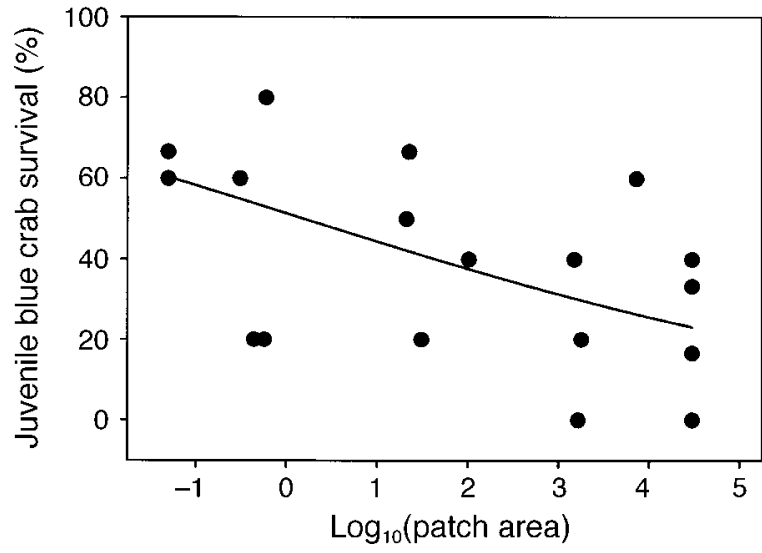

FIG. 4. Logistic regression results for the July tethering experiment. Data points denote frequency of crab survival at each site (data were pooled from all five 24-h trials for graphical representation).

\section{Crab tethering}

Influence of fragmentation on survival.-When artificial seagrass shoot density was held constant in July, relative blue crab survival was significantly negatively correlated with seagrass patch area (Fig. 4, Table 4). The probability that a juvenile blue crab survived 24 $\mathrm{h}$ of exposure to predators declined from $\sim 60 \%$ in the smallest patches to $<30 \%$ in continuous seagrass. No other explanatory variables (i.e., connectivity, proportional cover, crab size, and day of tethering) were significant at $P<0.05$, though there was a trend for lower survival in connected than in isolated fragmentation types, and a trend for reduced crab survival with increasing proportional seagrass cover.

Influence of fragmentation and shoot density on sur-

TABle 3. (A) Two-way ANOVA and (B) Student-Newman-Keuls (SNK) results for the shoot density measurements of Zostera marina in Chesapeake Bay, Virginia.

\begin{tabular}{lrrrc}
\hline \hline \begin{tabular}{l} 
A) ANOVA results \\
\multicolumn{1}{c}{ Source }
\end{tabular} & df & \multicolumn{1}{c}{ MS } & \multicolumn{1}{c}{$F$} & $P$ \\
\hline Time & 1 & 9921282.3 & 63.7 & $<0.001$ \\
Fragmentation type (FT) & 3 & 2032266.5 & 4.3 & 0.015 \\
Time $\times$ FT & 3 & 562648.1 & 1.2 & 0.33 \\
Residual & 24 & 3741761.8 & & \\
Total & 31 & 524450.3 & &
\end{tabular}

B) $\mathrm{SNK}$ results

\begin{tabular}{lcccc} 
Comparison & $\begin{array}{c}\text { SNK } \\
\text { difference }\end{array}$ & $g$ & $D \dagger$ & $P$ \\
\hline CS vs. LP & 406.8 & 3 & 488.6 & $\mathrm{~ns}$ \\
CS vs. SP & 18.3 & 2 & 404.8 & $\mathrm{~ns}$ \\
CS vs. VSP & 303.1 & 2 & 404.8 & $\mathrm{~ns}$ \\
LP vs. SP & 388.6 & 2 & 404.8 & $\mathrm{~ns}$ \\
LP vs. VSP & 709.9 & 4 & 538.9 & $* *$ \\
SP vs. VSP & 321.4 & 3 & 488.6 & $\mathrm{~ns}$ \\
\hline
\end{tabular}

Note: Abbreviations are as in Table 2.

$* * P<0.01$.

$\dagger D=(\text { EMS } / n)^{1 / 2} \times Q_{\mathrm{A}}$, with $n=8$; error mean square $($ EMS $)=139.6$ with $28 \mathrm{df} ; Q_{28,4,0.05}$

$=3.86, Q_{28,3,0.05}=3.50, Q_{28,2,0.05}=2.90$. 
TABLE 4. Logistic regression results for (A) the July crab tethering experiment and (B) the September crab tethering experiment in Chesapeake Bay, Virginia.

\begin{tabular}{lrrcr}
\hline \hline \multicolumn{1}{c}{ Source } & df & $\begin{array}{c}\text { Para- } \\
\text { meter }\end{array}$ & $P$ & Odds ratio $\dagger$ \\
\hline A) July tethering $\ddagger$ & & & & \\
$\quad$ Intercept & 1 & 0.05 & 0.8 & \\
$\log _{10}$ (patch size) & 1 & -0.28 & $<0.01$ & $0.75(0.62,0.92)$ \\
B) September tethering $\S$ & & & \\
Intercept & 1 & -0.97 & $<0.001$ & \\
Shoot density & 1 & -0.28 & $<0.001$ & $2.01(1.49,2.72)$ \\
\hline
\end{tabular}

$\dagger$ Odds ratio $=$ odds (surviving)/odds (not surviving); numbers in parentheses are lower and upper Wald confidence limits.

‡ Variables not meeting the $P<0.05$ significance for entry into the model: connectivity, proportional cover, crab size, and day of tethering.

$\S$ Variables not meeting the $P<0.05$ significance for entry into the model: fragmentation type and day of tethering.

vival.-Seagrass fragmentation had no effect on crab survival in September, but crab survival was positively correlated with artificial shoot density within all three fragmentation types (Fig. 5, Table 4). Shoot density was the only variable that entered into the model at $P$ $<0.05$. Only $15-30 \%$ of crabs survived in low density seagrass, whereas $40-52 \%$ of crabs survived in the intermediate density, and $61-65 \%$ of crabs survived in high density seagrass.

Temporal effects on crab survival.-Crab survival was higher in September than in July in all three fragmentation types (Fig. 6, Table 5). There was neither a difference in survival among the three fragmentation types nor an interaction effect of fragmentation type and time. Between $21 \%$ and $46 \%$ of crabs survived in early summer, whereas $61-65 \%$ of crabs survived in late summer.

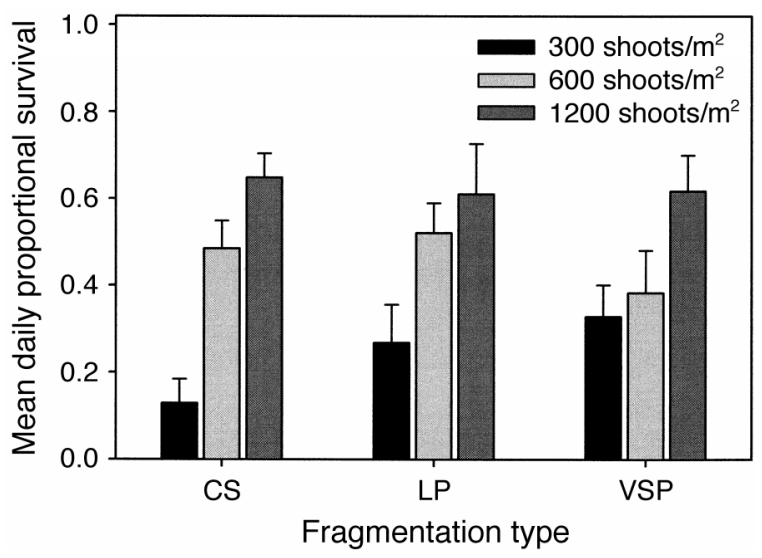

FIG. 5. Mean crab daily proportional survival (+1 SE) in low-density $\left(300\right.$ shoots $\left./ \mathrm{m}^{2}\right)$, intermediate-density $(600$ shoots $\left./ \mathrm{m}^{2}\right)$, and high-density (1200 shoots $\left./ \mathrm{m}^{2}\right)$ artificial seagrass plots placed in the continuous seagrass (CS), large patch (LP), and very small patch (VSP) fragmentation types in September 1998. Data have been combined for graphical representation.

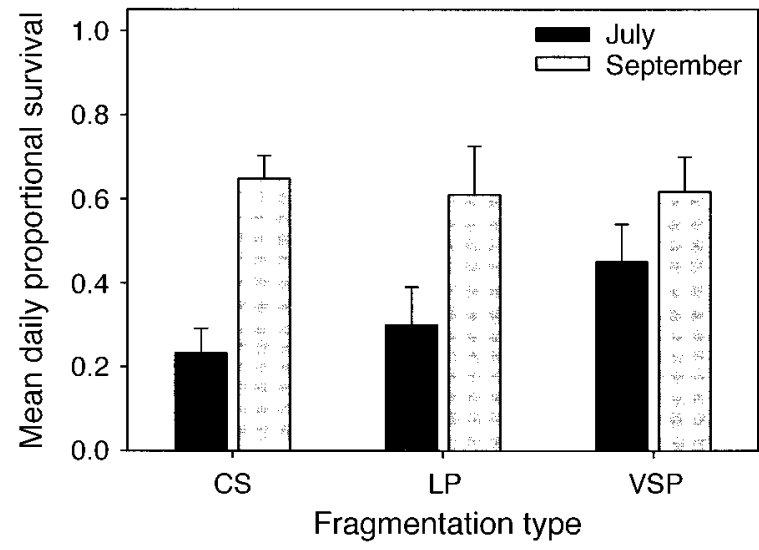

FIG. 6. Mean daily proportional survival (+1 SE) of juvenile blue crabs tethered in high density $\left(1200\right.$ shoots $\left./ \mathrm{m}^{2}\right)$ artificial eelgrass plots placed in the continuous seagrass (CS), large patch (LP), and very small patch (VSP) fragmentation types in July and September 1998. Data have been combined for graphical representation.

\section{Predator abundance}

The mean number of large crabs $(\geq 50 \mathrm{~mm} \mathrm{CW})$ captured in trawls differed significantly with fragmentation type (one-way ANOVA, $F=5.2, \mathrm{df}=3,12, P$ $<0.025$ ) (Fig. 7, Table 2). Crab abundance was significantly higher in continuous seagrass than in the large and very small patch fragmentation types, but abundance did not differ between continuous seagrass and small patches, or between large patches, small patches, and very small patches (Fig. 7). Of the crabs collected in trawls, $48 \%$ were found in continuous seagrass, $5 \%$ in the large patch fragmentation type, $26 \%$ in the small patch fragmentation type, and $6 \%$ in the very small patch fragmentation type. Predatory crab abundance was significantly lower in the isolated than in the connected fragmentation types ( $t$ test, $t=-3.92$, $\mathrm{df}=14, P<0.01 ;$ Fig. 7). Thus, the highest predatory crab densities were associated with the largest seagrass bed, either in the continuous core (continuous seagrass) or in the fringing small patches.

In the suction samples taken in seagrass, large crab density was highest in continuous seagrass, intermediate in large and small patches, and lowest in very small patches. The number of crabs captured in samples was relatively low (total $=34$ crabs) and highly variable. Large crab density did not differ significantly among fragmentation types (one-way ANOVA, $F=$

TABLE 5. $G$ test results for temporal effects on crab survival in the continuous seagrass, large patch, and very small patch fragmentation types.

\begin{tabular}{lccc}
\hline \hline \multicolumn{1}{c}{ Source } & df & $\chi^{2}$ & $P$ \\
\hline Fragmentation type & 2 & 0.12 & 0.94 \\
Month & 1 & 19.9 & $<0.001$ \\
Fragmentation type $\times$ month & 2 & 0.51 & 0.77 \\
\hline
\end{tabular}



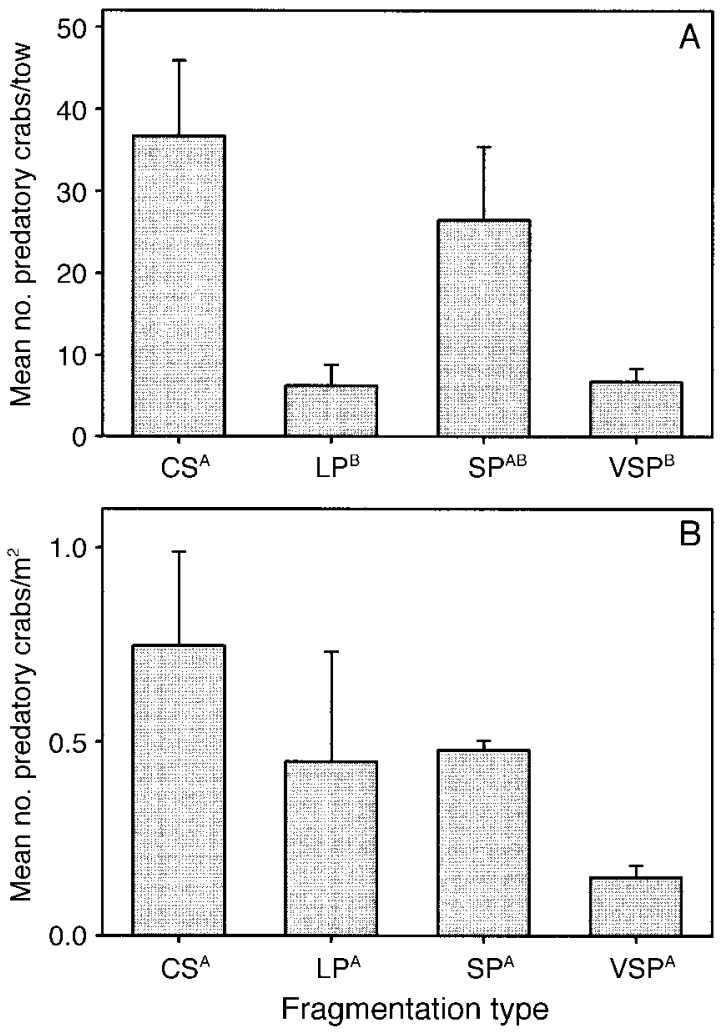

FIG. 7. Mean (+1 SE) number of blue crabs $>50 \mathrm{~mm}$ carapace width captured in (A) $n=4$ otter trawls of each fragmentation type and (B) $n=4$ suction samples taken in seagrass in each fragmentation type in August $1998(n=8$ suctions for continuous seagrass). Different superscript letters on fragmentation type abbreviations denote means that are significantly different at $P<0.05$. Fragmentation types are abbreviated as in Fig. 2.

$0.7, \mathrm{df}=3,16, P=0.5)$. Large crab density also did not differ significantly between seagrass and unvegetated sediment (paired $t$ test, $t=2.0$, df $=7, P=0.08$; Fig. 8) suggesting that trawls did not bias measures of crab abundance among patch sizes by sampling different proportions of seagrass in each fragmentation type. However, the relationship was nearly significant, and large crab density was more than two fold greater in seagrass patches than in unstructured bottom. Thus, our sampling may have been too limited to detect a significant difference in predatory crab abundance between seagrass and unvegetated sediment and between fragmentation types. Greater crab abundance in seagrass than in unvegetated sediment would result in spuriously low measures of predatory crabs in patchy seagrass, because the proportion of area trawled that was covered by seagrass was lower than in continuous seagrass. Results of the predator surveys should therefore be interpreted with caution.

Though large crab abundance was somewhat higher in July $(16.5 \pm 7.7$ crabs/tow, mean $\pm 1 \mathrm{SE})$ than in September $(13.2 \pm 3.2 \mathrm{crabs} / \mathrm{tow})$ in trawls of the lower

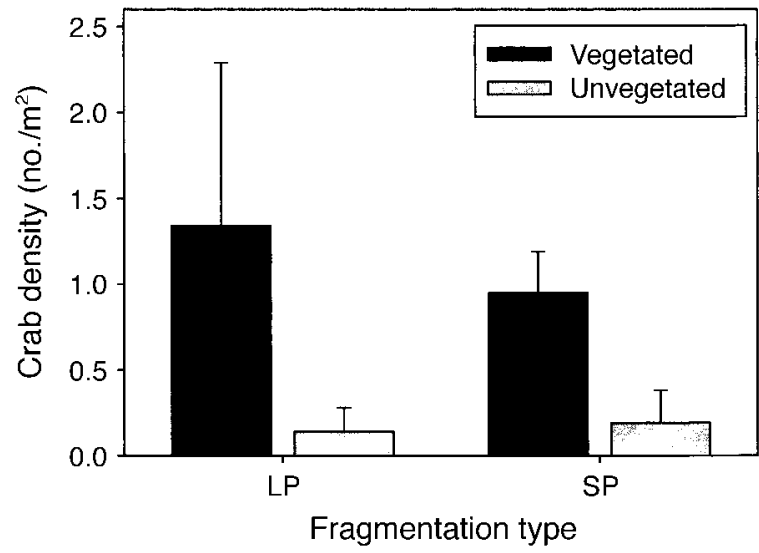

FIG. 8. Mean (+1 SE) density of large blue crabs captured in suction samples in vegetated $(n=4)$ and unvegetated $(n$ $=4$ ) bottom in the large patch (LP) and small patch (SP) fragmentation types.

York River, the difference was not significant ( $t$ test, $t$ $=-0.4$, df $=7, P=0.7$; Fig. 9).

\section{Treatment-specific bias experiments}

There was no significant interaction effect between tethering and shoot density on crab survival, demonstrating that a treatment-specific bias due to tethering was not present (Fig. 10, Table 6). Additionally, no bias in relative predation was found for juvenile blue crabs tethered in low density seagrass $\left(300\right.$ shoots $\left./ \mathrm{m}^{2}\right)$ vs. unvegetated sediment in the laboratory (Pile et al. 1996). Though we did not test for differences in relative survival between low and intermediate artificial shoot density, we witnessed no tangling of tethers with ar-

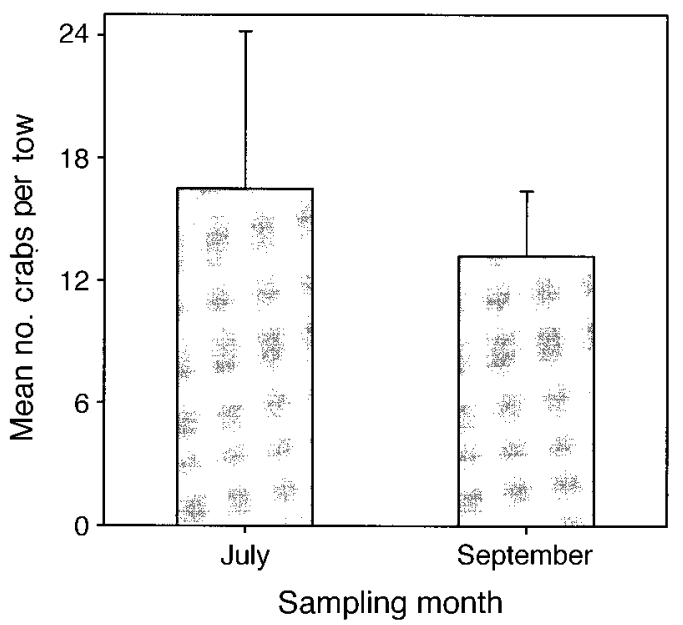

FIG. 9. Mean (+1 SE) number of crabs captured in trawls of the lower York River (Chesapeake Bay, Virginia) in June and September 1998. Means ( 1 SE) for each month were calculated from the mean number of crabs $>50 \mathrm{~mm}$ carapace width captured per tow ( $n=12-16$ tows/mo) in the Virginia Institute of Marine Science Trawl Survey. The means are not significantly different $(P>0.05)$. 


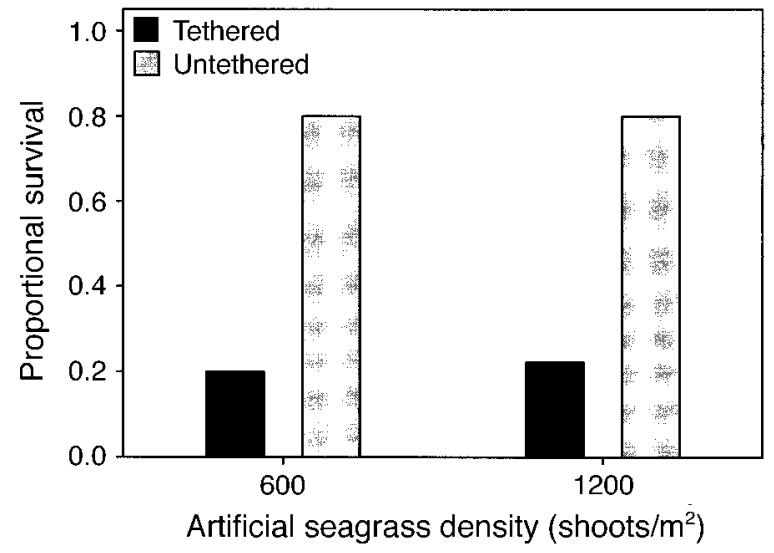

FIG. 10. Proportional survival of juvenile blue crabs placed in arenas with adult blue crabs in the laboratory experiment. Crabs were either tethered to plots that were 600 or 1200 shoots $/ \mathrm{m}^{2}$ or free to move about the arena (untethered). For each treatment combination, $n=12$ crabs. All crabs placed in arenas without adult blue crab predators (controls) were recaptured (see Methods: Treatment-specific bias experiments for more information).

tificial shoots in the laboratory. It is unlikely that crabs on tethers only $5 \mathrm{~cm}$ in length become tangled in shoots, especially at low and intermediate artificial shoot densities.

Survival was higher for untethered crabs than for tethered crabs. Though tethered crabs may swim, burrow, and hide behind seagrass shoots (Zimmer-Faust et al. 1994, Pile et al. 1996; K. A. Hovel, personal observation), they cannot swim away from predators, or avoid them if predators are detected in advance of an encounter. Thus, tethering experiments may overestimate natural crab mortality (Zimmer-Faust et al. 1994), but they provide an unbiased estimate of relative mortality among different seagrass densities.

\section{DISCUSSION}

In this experimental investigation of the effects of fragmentation in a marine ecosystem, the findings indicate that (1) blue crab survival is inversely related to patch size in a representative seagrass landscape, (2) the effect of patch size varies temporally, and (3) a covarying feature of fragmentation (shoot density) strongly influences crab survival independently of fragmentation effects. Thus, in this seagrass system, seagrass patch size, shoot density (i.e., habitat complexity), and temporal variation must be considered jointly when assessing the influence of habitat structure on faunal survival.

We removed the confounding effect of shoot density on survival and found an inverse relation between crab survival and patch size. This relation is opposite that for birds and mammals in many agricultural and urban landscapes (e.g., Wilcove 1985, Moller 1988, Small and Hunter 1988) and highlights the need for empirical research on fragmentation effects in a variety of habitat types. Specifically, the influence of landscape structure on predator and prey behavior and abundance must be quantified if the effects of habitat fragmentation on faunal survival are to be understood.

\section{Seagrass habitat fragmentation and crab survival}

The effects of seagrass habitat fragmentation and shoot density on faunal survival have been difficult to distinguish because of their covariation and seasonality. For instance, increased hard clam (Mercenaria mercenaria L.) survival in continuous vs. patchy seagrass in North Carolina may have been due to increased predator utilization of patchy seagrass, or to decreased predator ability to find and capture clams in the higher shoot densities of continuous seagrass (Irlandi 1994). In another study of hard clam survival, seagrass shoot density, seagrass root biomass, and clam survival all were greater in large than in small seagrass patches (Irlandi 1997). Thus, covariation in complexity and patch size has precluded an effective test of how landscape configuration influences survival of seagrass fauna. We eliminated the confounding effect of seagrass complexity and found that survival of blue crab juveniles was highest in small, isolated patches of seagrass. Our study is the first to demonstrate a negative correlation between prey survival and patch size in marine systems.

The inverse correlation between juvenile blue crab survival and seagrass patch size likely was due to a greater abundance of a chief predator (large blue crabs) in continuous than in fragmented habitat in our study. Results of our predator survey should be interpreted cautiously, as we sampled for large blue crabs only in midsummer, approximately one month after our July tethering experiment. However, the predator surveys revealed a trend for lower large blue crab (predator) abundance in fragmented seagrass habitat and in the smallest patches. Large blue crabs may remain in continuous seagrass because they are vulnerable to other crabs, birds, and fishes over unvegetated bottom (Micheli 1997). Large blue crab predation on bivalves was reduced in isolated habitat patches and higher in connected patches (Micheli and Peterson 1999). The largest patches of seagrass within a landscape may afford large blue crabs significant protection from higher order predation due to their lower edge-to-interior ratios, especially when crabs are most vulnerable (e.g., molting and mating; Ryer et al. 1997). Additionally, some large blue crab prey such as bivalves may be most

TABLE 6. $G$ test results for the laboratory experiment testing for crab-tethering treatment-specific bias for two shoot densities $\left(600\right.$ and 1200 shoots $\left./ \mathrm{m}^{2}\right)$ of eelgrass.

\begin{tabular}{lccc}
\hline \hline Source of variation & $\mathrm{df}$ & $\chi^{2}$ & $P$ \\
\hline Density & 1 & 0.01 & 0.9 \\
Tether & 1 & 11.6 & $<0.01$ \\
Density $\times$ tether & 1 & 0.01 & 0.9 \\
\hline
\end{tabular}


abundant in continuous seagrass (Peterson 1982). Thus, large blue crab predators may prefer continuous seagrass and large patches to small, isolated seagrass patches, which may reduce predator-prey encounter rates in fragmented seagrass habitat.

Alternatively, predators such as large blue crabs may not avoid fragmented areas, but their foraging efficiency may be reduced there. Crabs, fishes, or birds may have to search for appropriate feeding patches longer in fragmented seagrass, because patches are smaller and more dispersed.

Our results show that very small seagrass patches hold significant refuge value for juvenile blue crabs. In contrast, bay scallop survival was lower in closely spaced, small patches than in intermediate and large patches in Back Sound, North Carolina, though there was a trend for increased shoot densities with patch size (Irlandi et al. 1995). Irlandi et al. (1995) proposed that unvegetated channels between closely spaced, small seagrass beds facilitated the movement of large blue crabs, whelks, and other predators into beds, thereby increasing predation on scallops. Such corridors of unvegetated sediment between closely spaced seagrass patches may enable mobile predators to remain near cover while efficiently moving among beds in search of prey. Unvegetated sediment channels were present in our small patch fragmentation type (Fig. 2), but had the opposite effect on survival in our seagrass landscape; $50 \%$ of juvenile blue crabs survived in these patches whereas only $26 \%$ survived in continuous seagrass.

Our results support the notion that habitat fragmentation effects are dependent on landscape context (Donovan et al. 1997), and that predation rates reflect differences in predator abundance and distribution in different habitats, geographic regions, and landscape configurations (Andrén 1994, Tewksbury et al. 1998). The inverse correlation between juvenile blue crab survival and patch size contrasts studies demonstrating reduced songbird egg survival (Wilcove 1985, Small and Hunter 1988, Johnson and Temple 1990, Andrén 1992, Robinson et al. 1995) and increased nest parasitism (Brittingham and Temple 1983, Johnson and Temple 1990, Robinson et al. 1995) in small, isolated forest remnants relative to larger remnants. These studies describing negative effects of habitat fragmentation on fauna were conducted in Midwestern America and Scandinavia, where forests are fragmented by farmland. In these agricultural landscapes, nest predators such as corvids (Andrén 1992) and mammals (Angelstam 1986), and nest parasites such as cowbirds (Robinson et al. 1995) inhabit both cropland and forest. In contrast to large blue crabs, these predators and parasites move freely through the landscape matrix with little risk of predation; their high numbers in fragmented regions and patch-to-patch movements therefore increase predatorprey encounter rates in small, isolated patches with high proportional edge. However, some terrestrial pred- ators may prefer continuous to fragmented habitat, leading to positive effects of fragmentation on survival. For instance, forest fragmentation increased songbird breeding productivity in western Montana, because the abundance of red squirrels, a primary nest predator, declined as fragmentation increased (Tewksbury et al. 1998). Generalizations about the effects of habitat fragmentation and heterogeneity on prey survival therefore may be difficult, because of species- and habitat-specific responses of predators and prey to landscape structure.

It is important to note that our study on seagrass habitat fragmentation effects involved only one stage in the blue crab life cycle. Small juveniles are highly vulnerable to a variety of predators, and the abundance of adult and subadult blue crabs likely is strongly dependent on mortality of early juveniles such as those used in our study. However, the effect of seagrass habitat fragmentation on blue crab population size remains to be determined.

One caveat to the study is that experimental seagrass plots laid over unvegetated sediment differed from the other treatments, because plots placed in unvegetated sediment represent an addition of habitat rather than a replacement of a portion of seagrass patches as in the other treatments. These artificial eelgrass plots closely resembled natural Zostera marina patches, but did not provide olfactory cues to crabs. These factors may have caused survival to be great in these plots due to treatment-specific bias. This is unlikely, however, because structural additions to marine sediment attract blue crabs effectively (Schulman 1996, Eggleston et al. 1998). The relationship between crab survival and patch size was qualitatively unchanged and marginally significant $\left(\chi^{2}=3.1, P=0.07\right)$ if plots placed in unvegetated sediment are eliminated from the analysis.

\section{Effects of fragmentation and shoot density on crab survival}

Unlike early summer, fragmentation type had no influence on crab survival in September, probably due to alterations of the seagrass landscape in midsummer. Cownose rays foraged in the seagrass beds from midJuly to late August, apparently concentrating their destructive feeding in large patches of seagrass. Continuous seagrass and large patches were pockmarked with numerous depressions, $\sim 1 \mathrm{~m}$ wide $\times 0.3 \mathrm{~m}$ deep, which are characteristic of ray digging that fragments large patches into aggregations of smaller patches (Orth 1975, Smith and Merriner 1985; K. A. Hovel and R. N. Lipcius, personal observation). Differences in effective patch size among fragmentation treatments were therefore reduced in late summer, which may explain the lack of a significant difference in survival among these treatments.

Crab survival in late summer increased with shoot density in the artificial seagrass plots, irrespective of fragmentation treatment. Poor crab survival at low 
shoot densities was likely due to high detectability of small crabs by predators such as finfish and large blue crabs, which use chemical (Zimmer-Faust et al. 1994), tactile (Lipcius and Hines 1986, Eggleston 1990), and visual cues (Heck and Crowder 1991) when foraging.

\section{Temporal variation in crab survival}

Juvenile blue crab survival was higher in September than in July, despite seasonal increases in seagrass fragmentation and decreases in shoot density. These experiments require replication to determine whether the temporal patterns in survival are consistent seasonal phenomena, or instead were due to covarying factors or stochastic variation. However, we offer several potential hypotheses for why juvenile blue crab survival was higher in September than in July. First, increased survival may have been caused by emigration of predators from seagrass beds. If large blue crabs or other predators prefer continuous to fragmented seagrass, they may have left seagrass beds for other habitats after cownose rays fragmented continuous seagrass and large patches in midsummer. Large blue crabs also may leave seagrass beds in late summer if rays deplete their bivalve prey. Second, increased survival in September may have resulted from predator swamping by juvenile blue crabs. Peak blue crab recruitment in late summer (August-November; Orth and van Montfrans 1987, van Montfrans et al. 1990) often occurs as settlement pulses that may swamp predators, as evidenced by laboratory and field experiments demonstrating inverse densitydependent or density-independent juvenile crab mortality in benthic habitats (Pile 1993, van Montfrans et al. 1995, Moksnes et al. 1997). Abundance of small juvenile blue crabs $(3-30 \mathrm{~mm} \mathrm{CW})$ in seagrass beds at the Goodwin Islands was $\sim 2.3$-fold greater in September than in June 1998 (Hovel and Lipcius, unpublished manuscript), which may have reduced their overall mortality. Finally, seagrass shoot densities decreased from June to September, so that plot (artificial) shoot densities were lower than surrounding Zostera marina shoot densities in early summer but not in late summer. The relatively low plot shoot densities may have allowed predators to detect and capture crabs more easily in early than in late summer.

Temporal differences in survival also may have been due to changes in large blue crab (predator) abundance. Large blue crab abundance typically declines through the summer due to predation by birds, fishes, conspecifics (Micheli 1997), and fishery exploitation (Lipcius and Van Engel 1990). There was no significant difference, however, in lower York River crab abundance between early and late summer, 1998.

\section{Implications for restoration and conservation}

Quantifying the joint effects of seagrass shoot density, fragmentation, and time on survival is necessary to predict the effectiveness of seagrass restoration and stock-enhancement efforts. Recent widespread loss of seagrass due to sediment and nutrient loading (Orth and Moore 1983, Dennison et al. 1993), fishing gear, and propeller scarring (Sargent et al. 1995) has prompted efforts to restore seagrass to many coastal areas by seeding or shoot transplantation (Fonseca et al. 1999). However, seagrass transplanting is labor intensive, so that managers tasked with restoring seagrass often must choose between planting few large beds at low shoot densities, or many smaller beds at moderate or high shoot densities. Our results suggest that both the size of planted patches and the spacing of planted shoots will be critical determinants of faunal survival. Specifically, planting one large continuous area of seagrass at low shoot densities may not enhance blue crab survival as effectively as planting many smaller beds at high shoot densities.

Patchy seagrass may hold value for other seagrass epifauna as well as juvenile blue crabs. Grass shrimp (Palaemonetes spp.) densities were significantly higher in small $\left(0.25 \mathrm{~m}^{2}\right)$ artificial seagrass patches than in intermediate and large patches $\left(0.5-4.0 \mathrm{~m}^{2}\right)$ in Back Sound, North Carolina (Eggleston et al. 1998). Small isolated seagrass beds in high energy sites of Core and Back Sounds in North Carolina supported substantial densities of pink shrimp (Penaeus duorarum), though densities were significantly higher in continuous seagrass (Murphey and Fonseca 1995). More importantly, patchy vs. continuous beds served different functions for shrimp among seasons and through ontogeny, suggesting that both patchy and continuous seagrass beds deserve protection from destruction (Murphey and Fonseca 1995). Seagrass restoration may only enhance faunal abundance if a variety of bed spatial configurations are present.

Simple relationships between patch size and faunal survival are unlikely in seagrass, because of the strong effect of covarying complexity on survival. Relationships between seagrass habitat structure and faunal survival are made even more complex by dramatic temporal alterations in seagrass complexity and patch size. These changes may make spatial patterns in survival more difficult to quantify; however, seagrasses and other marine biogenic habitats provide excellent opportunities for determining how landscape change, which has received little attention, may influence landscape structure and function.

\section{ACKNOWLEDGMENTS}

We are grateful to M. Seebo, A. Bartholomew, J. van Montfrans, P. Gerdes, and W. Rose for field assistance. H. Squires and C. Durham also helped in the field as part of the Virginia Institute of Marine Science Governor's School Program. We thank D. Wilcox and R. J. Orth for GIS help, the Chesapeake Bay National Estuarine Research Reserve program for allowing us access to the study site, and Emmett Duffy, David Eggleston, Elizabeth Irlandi, and two anonymous reviewers for providing comments on an earlier version of the manuscript. We also thank the Willard A. Van Engel Foundation, the Chesapeake Bay Restoration Fund, Sigma Xi Grants-inAid-of-Research, the Lerner-Gray Fund for Marine Research, 
the Commonwealth of Virginia, Virginia Sea Grant, the Chesapeake Bay Stock Assessment Committee, and the VIMS Mini-Grant and Student Research Grant programs for financial support. Laboratory experiments were conducted in the Glucksman Experimental Mesocosm Laboratory at VIMS, made possible by a generous donation from Lewis Glucksman.

\section{Literature Cited}

Andrén, H. 1992. Corvid density and nest predation in relation to forest fragmentation: a landscape perspective. Ecology 73:794-804.

Andrén, H. 1994. Effects of habitat fragmentation on birds and mammals in landscapes with different proportions of suitable habitat: a review. Oikos 71:355-366.

Andrén, H., and P. Angelstam. 1988. Elevated predation rates as an edge effect in habitat islands: experimental evidence. Ecology 69:544-547.

Angelstam, P. 1986. Predation on ground-nesting bird's nests in relation to predator densities and habitat edge. Oikos 47: 365-373.

Bologna, P. A. X., and R. S. Steneck. 1993. Kelp beds as habitat for American lobster Homarus americanus. Marine Ecology Progress Series 100:127-134.

Brittingham, M. C., and S. A. Temple. 1983. Have cowbirds caused forest songbirds to decline? Bioscience 33:31-35.

Darnell, R. M. 1959. Study of the life history of the blue crab Callinectes sapidus Rathbun, in Louisiana waters. Transactions of the American Fisheries Society 89:294304.

Dayton, P. K., V. Currie, T. Gerrodette, B. D. Keller, R. Rosenthal, and D. Ven Tresca. 1984. Patch dynamics and stability of some California kelp communities. Ecological Monographs 54:253-289.

Dayton, P. K., and M. J. Tegner. 1984. The importance of scale in community ecology: a kelp forest example with terrestrial analogs. Pages 457-481 in P. W. Price, C. N. Slobodchikoff, and W. S. Gaud, editors. A new ecology: novel approaches to interactive systems. J. Wiley and Sons, New York, New York, USA.

Dennison, W. C., R. J. Orth, K. A. Moore, J. C. Stevenson, V. Carter, S. Kollar, P. W. Bergstrom, and R. A. Batiuk. 1993. Assessing water quality with submersed aquatic vegetation. BioScience 43:86-94.

Donovan, T. M., P. W. Jones, E. M. Annand, and F. R. Thompson III. 1997. Variation in local-scale edge effects: mechanisms and landscape context. Ecology 78:2064-2075.

Eggleston, D. B. 1990. Behavioral mechanisms underlying variable functional responses of blue crabs, Callinectes sapidus, feeding on juvenile oysters Crassostrea virginica. Journal of Animal Ecology 59:615-630.

Eggleston, D. B., L. L. Etherington, and W. E. Elis. 1998. Testing landscape ecological principles in the marine environment: scale- and habitat-dependent recruitment of decapod crustaceans. Journal of Experimental Marine Biology and Ecology 223:111-132.

Eggleston, D. B., R. N. Lipcius, D. L. Miller, and L. CobaCetina. 1990. Shelter scaling regulates survival of juvenile Caribbean spiny lobster Panulirus argus. Marine Ecology Progress Series 62:79-88.

Fonseca, M. S., W. J. Kenworthy, and G. W. Thayer. 1999. Guidelines for the conservation and restoration of seagrasses in the United States and adjacent waters. National Oceanic and Atmospheric Administration, Decision Analysis Series 12, Silver Spring, Maryland, USA.

Fonseca, M. S., J. C. Zieman, G. W. Thayer, and J. S. Fisher. 1982. Influence of the seagrass, Zostera marina, on current flow. Estuarine, Coastal and Shelf Science 15:351-364.

Forman, R. T. T., and M. Godron. 1981. Patches and structural components for a landscape ecology. Bioscience 31:733740 .
Forman, R. T. T., and M. Godron. 1986. Landscape ecology. Wiley, New York, New York, USA.

Gates, J. E., and L. W. Gysel. 1978. Avian nest dispersion and fledgling success in field-forest ecotones. Ecology 59: 871-883.

Heck, K. L., and L. B. Crowder. 1990. Habitat structure and predator-prey interactions. Pages 281-299 in S. Bell, E. McCoy, and H. Mushinsky, editors. Habitat complexity: the physical arrangement of objects in space. Chapman and Hall, New York, New York, USA.

Heck, K. L., Jr., and R. J. Orth. 1980. Seagrass habitats: the roles of habitat complexity, competition and predation in structuring associated fish and motile macroinvertebrate assemblages. Pages 469-494 in V. S. Kennedy, editor. Estuarine perspectives. Academic Press, New York, New York, USA

Heck, K. L., Jr., and T. A. Thoman. 1981. Experiments on predator-prey interactions in vegetated aquatic habitats. Journal of Experimental Marine Biology and Ecology 53: $125-134$.

Heck, K. L., and K. A. Wilson. 1987. Predation rates on decapod crustaceans in latitudinally separated seagrass communities: a study of spatial and temporal variation using tethering techniques. Journal of Experimental Marine Biology and Ecology 107:87-91.

Hines, A. H., A. H. Haddon, and L. A. Weichert. 1990. Guild structure and foraging impact of blue crabs and epibenthic fish in a subestuary of Chesapeake Bay. Marine Ecology Progress Series 67:105-126.

Hosmer, D. W., and S. Lemeshow. 1989. Applied logistic regression. Wiley, New York, New York, USA.

Irlandi, E. A. 1994. Large- and small-scale effects of habitat structure on rates of predation: how percent coverage of seagrass affects rates of predation and siphon nipping on an infaunal bivalve. Oecologia 98:176-183.

Irlandi, E. A. 1997. Seagrass patch size and survivorship of an infaunal bivalve. Oikos 78:511-518.

Irlandi, E. A., W. G. Ambrose Jr., and B. A. Orlando. 1995. Landscape ecology and the marine environment: how spatial configuration of seagrass habitat influences growth and survival of the bay scallop. Oikos 72:307-313.

Johnson, R. G., and S. A. Temple. 1990. Nest predation and brood parasitism of tallgrass prairie birds. Journal of Wildlife Management 54:106-111.

Keitt, T. H., D. L. Urban, and B. T. Milne. 1997. Detecting critical scales in fragmented landscapes: Conservation Ecology 1(1):4[online: 〈http://www.consecol.org/vol1/issl/art4〉]

Keyser, A. J., G. E. Hill, and E. C. Soehren. 1998. Effects of forest fragment size, nest density, and proximity to edge on the risk of predation to ground-nesting passerine birds. Conservation Biology 12:986-994.

Lipcius, R. N., D. B. Eggleston, D. L. Miller, and T. C. Luhrs. 1998. The habitat-survival function for Caribbean spiny lobster: an inverted size effect and non-linearity in mixed algal and seagrass habitats. Marine and Freshwater Research 49:807-816.

Lipcius, R. N., and A. H. Hines. 1986. Variable functional responses of a marine predator in dissimilar homogeneous microhabitats. Ecology 67:1361-1371.

Lipcius, R. N., and W. A. Van Engel. 1990. Blue crab population dynamics in Chesapeake Bay: variation in abundance (York River, 1972-1988) and stock-recruit functions. Bulletin of Marine Science 46:180-194.

Mansour, R. A. 1992. Foraging ecology of the blue crab, Callinectes sapidus Rathbun, in lower Chesapeake Bay. Dissertation. The College of William and Mary, School of Marine Science, Gloucester Point, Virginia, USA.

Martin, T. H. R., A. Wright, and L. B. Crowder. 1989. Nonadditive impact of blue crabs and spot on their prey assemblages. Ecology 70:1935-1942. 
McConaugha, J. R. 1988. Export and reinvasion of larvae as regulators of estuarine decapod populations. American Fisheries Society Symposium 3:90-103.

Micheli, F. 1997. Effects of predator foraging behavior on patterns of prey mortality in marine soft bottoms. Ecological Monographs 67:203-224.

Micheli, F., and C. H. Peterson. 1999. Estuarine vegetated habitats as corridors for predator movements. Conservation Biology 13:869-881.

Moksnes, P. O., R. N. Lipcius, L. Pihl, and J. van Montfrans. 1997. Cannibal-prey dynamics in juveniles and postlarvae of the blue crab. Journal of Experimental Marine Biology and Ecology 215:157-187.

Moller, A. P. 1988. Nest predation and nest site choice in passerine birds in habitat patches of different size: a study of magpies and blackbirds. Oikos 53:215-221.

Moody, K. E. 1994. Predation on juvenile blue crabs, Callinectes sapidus Rathbun, in lower Chesapeake Bay: patterns, predators, and potential impacts. Dissertation. The College of William and Mary, School of Marine Science, Gloucester Point, Virginia, USA.

Murphey, P. L., and M. S. Fonseca. 1995. Role of high and low energy seagrass beds as nursery areas for Penaeus duorarum in North Carolina. Marine Ecology Progress Series 121:91-98.

Orth, R. J. 1975. Destruction of eelgrass, Zostera marina, by the cownose ray, Rhinoptera bonasus, in the Chesapeake Bay. Chesapeake Science 16:205-208.

Orth, R. J. 1977. The importance of sediment stability in seagrass communities. Pages 281-300 in B. C. Coull, editor. Ecology of marine benthos. University of South Carolina Press, Columbia, South Carolina, USA.

Orth, R. J. 1992. A perspective on plant-animal interactions in seagrasses: physical and biological determinants influencing plant and animal abundance. Pages 147-164 in D. M. John, S. J. Hawkins, and J. H. Price, editors. Plantanimal interactions in the marine benthos. Clarendon Press, Oxford, UK.

Orth, R. J., K. L. Heck Jr., and J. van Montfrans. 1984. Faunal communities in seagrass beds: a review of the influence of plant structure and prey characteristics in predator-prey relationships. Estuaries 7:339-350.

Orth, R. J., and K. A. Moore. 1983. Chesapeake Bay: an unprecedented decline in submerged aquatic vegetation. Science 222:51-53.

Orth, R. J., and K. A. Moore. 1986. Seasonal and year-toyear variations in the growth of Zostera marina L. (eelgrass) in the lower Chesapeake Bay. Aquatic Botany 24: 335-341.

Orth, R. J., J. F. Nowak, G. F. Anderson, D. J. Wilcox, J. R. Whiting, and L. S. Nagey. 1996. Distribution of submerged aquatic vegetation in the Chesapeake Bay and tributaries and Chincoteague Bay-1995. Final Report to the U.S. Environmental Protection Agency, Annapolis, Maryland, USA.

Orth, R. J., and J. van Montfrans. 1987. Utilization of a seagrass meadow and tidal marsh creek by blue crabs $\mathrm{Cal}$ linectes sapidus. I. Seasonal and annual variations in abundance with emphasis on post-settlement juveniles. Marine Ecology Progress Series 41:283-294.

Paine, D. P. 1981. Aerial photography and image interpretation for resource management. John Wiley and Sons, New York, New York, USA.

Paton, P. W. C. 1994. The effect of edge on avian nest success: How strong is the evidence? Conservation Biology 8:1726.

Peery, C. A. 1989. Cannibalism experiments on the blue crab (Callinectes sapidus Rathbun): potential effects on size and abundance. Thesis. The College of William and Mary, School of Marine Science, Glouester Point, Virginia, USA.
Petersen, C. G. L. 1918. The sea bottom and its production of fish foods; a survey of the work done in connection with valuation of Danish waters from 1883-1917. Report of the Danish Biological Station 21:1-62.

Peterson, C. H. 1982. Clam predation by whelks (Busycon spp.): experimental tests of the importance of prey size, prey density, and seagrass cover. Marine Biology 66:159170.

Peterson, Ch. H., and R. Black. 1994. An experimentalist's challenge: when artifacts of intervention interact with treatments. Marine Ecology Progress Series 111:289-297.

Pile, A. J. 1993. Effects of habitat and size-specific predation on the ontogenetic shift in habitat use by newly-settled blue crabs. Thesis, The College of William and Mary, School of Marine Science, Gloucester Point, Virginia, USA.

Pile, A. J., R. N. Lipcius, J. van Montfrans, and R. J. Orth. 1996. Density-dependent settler-recruit-juvenile relationships in blue crabs. Ecological Monographs 66:277-300.

Robbins, B. D., and S. S. Bell. 1994. Seagrass landscapes: a terrestrial approach to the marine subtidal environment. Trends in Ecology and Evolution 9:301-304.

Robinson, S. K., F. R. Thompson III, T. M. Donovan, D. R. Whitehead, and J. Faaborg. 1995. Regional forest fragmentation and the nesting success of migratory birds. Science 267:1987-1990.

Ryer, C. H., J. van Montfrans, and K. E. Moody. 1997. Cannibalism, refugia and the molting blue crab. Marine Ecology Progress Series 147:77-85.

Sargent, F. J., T. J. Leary, D. W. Crewz, and C. R. Kreuer. 1995. Scarring of Florida's seagrasses: assessment and management options. Florida Department of Environmental Protection, Florida Marine Research Institute Technical Report TR-1, St. Petersburg, Florida, USA.

SAS. 1990. SAS/STAT users guide. Version 6.09, Fourth edition, Volume 2. SAS Institute, Cary, North Carolina, USA.

Saunders, D. A., R. J. Hobbs, and C. R. Margules. 1991. Biological consequences of ecosystem fragmentation: a review. Conservation Biology 5:18-32.

Schulman, J. L. 1996. Habitat complexity as a determinant of juvenile blue crab survival. Thesis. The College of William and Mary, School of Marine Science, Glouester Point, Virginia, USA.

Small, M. F., and M. L. Hunter. 1988. Forest fragmentation and avian nest predation in forested landscapes. Oecologia 76:62-64.

Smith, J. W., and J. V. Merriner. 1985. Food habits and feeding behavior of the cownose ray, Rhinoptera bonasus, in lower Chesapeake Bay. Estuaries 8:305-310.

Sokal, R. R., and F. J. Rohlf. 1995. Biometry. Third edition. W.H. Freeman and Company, New York, New York, USA.

Stoner, A. W. 1979. Species-specific predation on amphipod cructacea by the pinfish Lagodon rhomboides: mediation by macrophyte standing crop. Marine Biology 55:201-207.

Tagatz, M. E. 1968. Biology of the blue crab, Callinectes sapidus, in the St. John River, FL. United States Fisheries Bulletin 67:17-33.

Tewksbury, J. J., S. J. Heil, and T. E. Martin. 1998. Breeding productivity does not decline with increasing fragmentation in a western landscape. Ecology 79:2890-2903.

Townsend, E. C., and M. S. Fonseca. 1998. Bioturbation as a potential mechanism influencing spatial heterogeneity of North Carolina seagrass beds. Marine Ecology Progress Series 169:123-132.

Underwood, A. J. 1997. Experiments in ecology: their logical design and interpretation using analysis of variance. Cambridge University Press, Cambridge, UK.

Van Engel, W. A. 1958. The blue crab and its fishery in Chesapeake Bay. Part 1-Reproduction, early development, 
growth, and migration. Commercial Fisheries Review 20: 6-17.

van Montfrans, J., C. E. Epifanio, D. M Knott, R. N. Lipcius, D. J. Mense, K. S. Metcalf, E. J. Olmi III, R. J. Orth, M. H. Posey, E. L. Wenner, and T. L. West. 1995. Settlement of blue crab postlarvae in western North Atlantic estuaries. Bulletin of Marine Science 57:834-854.

van Montfrans, J., C. A. Peery, and R. J. Orth. 1990. Daily, monthly and annual settlement patterns by Callinectes sapidus and Neopanope sayi on artificial collectors deployed in the York River, Virginia. Bulletin of Marine Science 46: 214-228.

Villard, M. A., M. K. Trzcinski, and G. Merriam. 1999. Fragmentation effects on forest birds: relative influence of woodland cover and configuration on landscape occupancy. Conservation Biology 13:774-783.

Wilcove, D. S. 1985. Nest predation in forest tracts and the decline of migratory songbirds. Ecology 66:1211-1214.

Williams, A. B. 1984. Shrimps, lobsters, and crabs of the Atlantic coast of the Eastern United States, Maine to Florida. Smithsonian Institution Press, Washington, D.C. USA.

Wilson, K. A., K. L. Heck, and K. W. Able. 1987. Juvenile blue crab, Callinectes sapidus, survival: an evaluation of eelgrass, Zostera marina, as refuge. Fisheries Bulletin 85: 53-58.

Zimmer-Faust, R. K., D. R. Fielder, K. L. Heck, L. D. Coen, and S. G. Morgan. 1994. Effects of tethering on predatory escape by juvenile blue crabs. Marine Ecology Progress Series 111:299-303. 